\title{
A HISTORICAL INQUIRY INTO THE RIGHT TO TRIAL BY JURY IN COMPLEX CIVIL LITIGATION *
}

\author{
Morris S. ARnoLd $\dagger$
}

Readers of recent law reviews and reports will not need to be told that in the last few years a very considerable controversy has arisen over the availability of jury trial in complex civil cases. ${ }^{x}$ In all the commentary addressed to this issue it seems to have escaped remark that there is nothing very new in attempts by certain interests to avoid jury trial. For instance, well over a century ago Hunt's Merchants' Magazine lamented the "frequent inability of jurors to agree" in commercial cases." In part because "merchants tended to believe that in cases involving complex commercial issues . . . a single judge was likelier to understand the case and thus be more reliable than a jury," they "preferred whenever possible to bring suit in equity." 3 We are today witnessing a recrudescence of such efforts.

Some who argue that juries need not be employed in complicated civil litigation maintain that juries are incapable of rendering

- Professor Arnold's Article was commissioned by counsel for the plaintiffs in Zenith Radio Corp. v. Matsushita Elec. Indus. Co., 478 F. Supp. 889 (E.D. Pa.), interlocutory appeal granted, No. 79-2540 (3d Cir. Sept. 20, 1979) (argued Feb. 14, 1980), and was submitted in unedited form to the Court of Appeals for the Third Circuit in connection with that suit. Readers interested in an opposing viewpoint on the history of the right to jury trial in complex civil litigation may wish to read the Article by Lord Devlin, commissioned by counsel to the International Business Machines Corporation, which appeared in 80 Corom. L. Rev. 43 (1980), as well as the reply to Professor Arnold by Messts. Campbell and Le Poidevin in the Discussion section of this issue. [The Editors].

† Professor of Law and History, and Vice President-Director of the Office of the President, University of Pennsylvania. B.S.E.E. 1965, L.L.B. 1968, University of Arkansas; LL.M. 1969, S.J.D. 1971, Harvard University.

I E.g., In re U.S. Financial Sec. Litig., 609 F.2d 411 (9th Cir. 1979); Zenith Radio Corp. v. Matsushita Elec. Indus. Co., 478 F. Supp. 889 (E.D. Pa. 1979), interlocutory appeal granted, No. 79-2540 (3d Cir. Sept. 20, 1979) (argued Feb. 14, 1980); Devlin, Jury Trial of Complex Cases: English Practice at the Time of the Seventh Amendment, 80 Colum. L. Rev. 43 (1980); Comment, The Right to an Incompetent Jury: Protracted Commercial Litigation and the Seventh Amendment, 10 Cons. L. Rev. 775 (1978); Note, The Right to a Jury Trial in Complex Civil Litigation, 92 Harv. L. Rev. 898 (1979); Note, Jury Trials in Complex Litigation, 53 ST. John's L. Rev. 751 (1979); Note, Preserving the Right to Jury Trial in Complex Civil Cases, 32 Stan. L. Rev. 99 (1979) (and cases cited therein at 99 n.2); Note, The Right to Trial by Jury in Complex Litigation, 20 WM. \& Mary L. Rev. 329 (1978); Campbell, A Historical Basis for Banning Juries, Nat'l L.J., Feb. 11, 1980, at 17, col. 1 .

2 DeForest, Trial by Jury in Commercial Cases, 35 Hunt's Menchants' Mag. 302,304 (1856).

3 T. Freyer, Forums of Order: The Federal Courts and Busaness in AMERTCAN HISTORY 40-41 (1979). 
intelligent and informed verdicts in complex cases; hence the remedies at law are inadequate ${ }^{4}$ and equitable jurisdiction appropriate. $^{5}$ Because all the authorities seem to agree that the right to jury trial in the federal courts is to be determined, at least in part, by reference to the practices contemporaneous with the adoption of the seventh amendment in 1791,6 proponents of the "complexity exception" have attempted to discover a historical foundation for their theory. They purport to find in eighteenthcentury English law a well-established head of equity jurisdiction that allowed the defendant, as well as the plaintiff, to insist on avoiding jury trial in cases involving complicated facts. ${ }^{7}$ This Article will attempt to show that this view is misconceived in a number of important and fatal ways: not only is it a view at odds with the current of American legal thought in the late eighteenth century, it is also without general support in the English authorities of that age. ${ }^{8}$

\section{Equity in Eighteenth-Gentury America}

Mr. Justice Story wrote in an opinion early in the nineteenth century that the common law alluded to in the seventh amendment was "[b]eyond all question . . . not the common law of any individual state, (for it probably differs in all), but it is the common

4 This argument confuses improbability with impossibility. For a remedy at law to be inadequate the just remedy must be unavailable to the plaintiff. For example, an award of money damages would be inadequate for the disappointed purchaser of land, because no two pieces of real property are alike. The just remedy-an order transferring the property-would be impossible to obtain in a court of law; hence the available remedy would be inadequate.

However limited the capacity of a jury to understand issues in complex litigation, a just remedy at law is not unavailable to the plaintiff. Although the limitations of the jury may indeed render a just and adequate remedy less probable than if the suit were tried in equity, that remedy is nevertheless always a possible one.

The suggestion that the jury's lack of sophistication operates to deny the plaintiff an adequate remedy at law is really a complaint about denial of due process, dressed in the formality of the rules of pleading. A plaintiff seeking damages is certainly in the right court, and properly before a jury. Whether a jury is the best possible trier of fact is an issue unrelated to the adequacy of the remedy.

5 See, e.g., Devlin, supra note 1 .

6 In Suits at common law, where the value in controversy shall exceed twenty dollars, the right of trial by jury shall be preserved, and no fact tried by a jury, shall otherwise be reexamined in any Court of the United States, than according to the rules of the common law.

U.S. Const. amend. VII. See, e.g., Wolfram, The Constitutional History of the Seventh Amendment, 57 MinN. L. REv. 639, 639-40 (1973).

7 Devlin, supra note 1 , at 72 et seq.

8 This Article assumes, without addressing, the correctness of the view that the scope of the seventh-amendment right to jury trial is determined by the distinction between legal and equitable claims as it existed in 1791 . 
law of England, the grand reservoir of all our jurisprudence." 9 This statement has been understood to mean that the right to jury trial in the federal courts should be determined solely by reference to the eighteenth-century English practice.10 In fact, however, the exact question involved in the case before Story was whether federal courts should apply the Massachusetts practice of giving a right to jury trial on appeal. Story's dictum thus has no bearing on our inquiry, for we are not concerned with what sort of jury trial the Constitution would require in a case conceded to be at law; our question is rather where the boundary between legal and equitable jurisdiction lay at the time of the adoption of the seventh amendment.

Although our focus is different from Story's, it is nevertheless true that the line between law and equity may have been drawn differently from colony to colony; we know, for instance, that in the Confederation period, equity procedure differed somewhat from place to place. ${ }^{11}$ Yet the variety of colonial and state practice in the latter part of the eighteenth century is relevant to the question of the scope of the seventh-amendment right in at least three ways. First, and most important, it exposes to view the sentiment for and attachment to trial by jury that Americans had in the nascent period of the nation. That special affection for the jury ought to be viewed as relevant not just to the fact that jury trial was "preserved" in the Constitution; it is relevant as well to interpreting the scope of the actual provision, for it gives the right granted an aura, and the Constitution a meaning, they would not otherwise have if the institution of jury trial had been regarded more or less indifferently. Second, especially in those places in which the English brand of common law was consciously regarded as the model to emulate, the American practice in 1791 is some evidence of what Americans thought the English practice was. Third, the United States Supreme Court has itself stated that the seventhamendment "guaranty has always been construed to mean a trial in the mode and according to the settled rules of the common law, including all the essential elements recognized in this country and $16,750)$.

9 United States v. Wonson, 28 F. Cas. 745, 750 (C.C.D. Mass. 1812) (No.

10 See Wolfram, supra note 6, at 639-42. "No federal case decided after Wonson seems to have challenged this sweeping proclamation; perhaps later judges have hesitated to appear to be the kind of intractable person that would require Mr. Justice Story to elaborate on the obvious." Id. 641 .

11 See J. Goeber, 1 History of the Strpreane Court of the United States $580-89$ (1971). 
England when the Constitution was adopted." ${ }^{12}$ In an inquiry intended to uncover the original understanding of those who drafted and ratified the seventh amendment, eighteenth-century American attitudes toward courts of equity cannot therefore be unimportant. A short review of what can be discovered about these matters will thus be attempted.

\section{A. Equity and Trial by Jury}

In The Federalist No. 83, Alexander Hamilton revealed himself to be something of an admirer of equitable jurisdiction. Discussing the proposal for a constitutional provision regarding jury trial, he predicted that "to extend the jurisdiction of the courts of law to matters of equity . . . will tend gradually to change the nature of the courts of law, and to undermine the trial by jury, by introducing questions too complicated for a decision in that mode." 13 But there is every reason to think that Hamilton's views on this matter were, as on some others, somewhat idiosyncratic. Indeed, Professor Katz has said that "[f]ew American politicians of the colonial era would have seen equity law and chancery courts in such a favorable light." 14 Katz went on to note that "no colonial legal institution was the object of such sustained and intense political opposition as the courts dispensing equity law." 15 Virtually absent from the colonies in the seventeenth century, regular courts of equity existed in only five of the thirteen original states in $1791 ;{ }^{16}$ and in the eighteenth century equity courts found themselves in the center of a storm of controversy. Much of this opposition was of a political character, focusing on the power to create such courts, and the authority to appoint their members, rather than the content of equity doctrine. ${ }^{17}$ But much of the opposition was also due to the unavailability of a jury in regular chancery practice. ${ }^{18}$ Indeed, in some of the apparently "political" opposition

12 Continental Ill. Nat'l Bank \& Trust Co. v. Chicago, R.I. \& Pac. Ry., 294 U.S. 648,669 (1935).

13 The Federatist No. 83, at 528 (A. Hamilton) (B. Wright ed. 1961).

$14 \mathrm{Katz}$, The Politics of Law in Colonial America: Controversies over Chancery Courts and Equity Law in the Eighteenth Century, in 5 Perspectives IN AMEricair History 257, 257 (D. Fleming \& B. Bailyn eds. 1971).

15 Id. $257-58$.

$16 \mathrm{~J}$. GoEbEI, supra note 11 , at 580 .

17 W. Rawle, Equtry in Pennsylvanta 53-54 (Philadelphia 1868); Katz, supra note 14 , at $282-83$.

${ }^{18}$ L. Frifodan, A History of American Law 47-48 (1973); Katz, supra note 14, at 272; Smith \& Hershkowitz, Courts of Equity in the Province of New York: The Cosby Controversy, 1732-1736, 16 AM. J. OF LEGAr Hist. 1, 50 (1972). 
to equity, opposition which emphasized the centralized character of equity in contrast to the decentralized trials of the common law, it is right to see an affection for the rough and tumble of nisi prius verdicts in preference to a decision by one man alone. Juries were often regarded as more than a "mode of trial": they were instruments of local government as well.

In New York, a good deal of the opposition to equity courts was due to the lack of jury trials in those forums. ${ }^{19}$ In the early part of the century an enormous stir was occasioned by the litigation between Governor William Cosby and Rip Van Dam over which of them was entitled to the salary and perquisites of the governorship. ${ }^{20}$ When Cosby, through the power of his office, maneuvered the controversy into the court of exchequer, many thought that he had done so in order to avoid a jury trial. ${ }^{21}$ Moreover, Cosby's creation of a court of equity was perceived as motivated by a desire to deprive the colonists of their right to trial by jury; ${ }^{22}$ and some complained that "trials by juries are taken away when a governor pleases." 23 Thus in early eighteenth-century New York the popular association of equity with arbitrary power may be readily established, and in the 1760 s the right to trial by jury was even more strenuously asserted and insisted upon in the controversy over equity courts. ${ }^{24}$

It would in fact be extremely surprising if the opposition to chancery were not in some measure directly linked to the colonists' high regard for the jury. As in medieval England, ${ }^{25}$ juries in eighteenth-century America had much more power to decide questions both of law and fact than do modern ones. This has been documented best in the case of Massachusetts, ${ }^{26}$ but there is good reason to believe that the Massachusetts experience was in this respect not unlike that in most American colonies. ${ }^{27}$ Most of the

19 Smith \& Hershkowitz, supra note 18, at 36-37.

20 See generally Katz, stipra note 14, at 277-82; Smith \& Hershkowitz, supra note 18.

21 Smith \& Hershkowitz, supra note 18 , at 19 n.49.

22 Id. 3I-32.

23 New York Weekly Journal, No. 23, Apr. 8, 1734, reprinted in J. ArEXANDER, A Bruef Narrative of the Case and Trtal of Jobin Petrer Zenger app. A, at 134, 136 (S. Katz ed. 1963). See Smith \& Hershkowitz, supra note 18, at 40 \& n.100.

24 Smith \& Hershkowitz, supra note 18, at 50.

25 See generally Arnold, Law and Fact in the Medieval Jury Trial: Out of Sight, Out of Mind, 18 Aas. J. OF Legax HIST. 267 (1974).

26 See generally W. NeIson, The Amerrcantzation of the Common Law 21-30, 165-71 (1975).

27 Nelson, The Eighteenth Century Background of John Marshall's Constitutional Jurisprudence, 76 MrCH. L. REv. 893, 904-17 (1978). 
jury-control techniques which modern lawyers take for granted were simply unknown in early American practice, ${ }^{28}$ and other technical devices which have as their aim and effect the control of the jury were unavailable as well. For instance, special pleading, the purpose of which is partly to circumscribe the jury's scope of operation and thus to limit its discretion, was extremely rare. ${ }^{29}$ Many important eighteenth-century Americans recognized that this gave juries the power and authority to decide law; indeed, they applauded that capacity. John Adams, using a metaphor which tells us a great deal about the natural-law orientation of early Americans, said that the common law was known to all "and imbibed with the Nurses Milk and first Air." 30 Professor NeIson's description of the effect of this view of the law is worth quoting at length:

Lawyers thus believed that juries should have the power to find law, apparently so that they could serve when needed as a restraint on judicial power. The lawfinding power of juries had a number of consequences, however, that appear to have been unanticipated. One set of consequences arose out of the fact that law found by juries to fit the circumstances of individual cases has great potential for flexibility, for records of jury determinations of points of law are seldom preserved, and hence those determinations do not become precedents with a binding effect on future juries. In each case, a jury is free, if justice requires, to reach the same result reached by other juries in analogous cases in the past; if, on the other hand, justice requires departure from past verdicts, the jury is free so to depart. Moreover, no record is kept of such departures, and therefore legal change and development are imperceptible; men have the valuable illusion of legal stability. Explicit rules of law, such as the rules of pleading considered above, remain unchanged, while substantive law is still extremely flexible in its ability to adapt itself to social needs in individual cases. The broad power of juries to find law thus gave the legal system real flexibility while simultaneously giving the illusion of stability-two values that are important in doing justice in individual cases and in convincing litigants that justice has been done them.

The law-finding power of juries also made possible adherence to the doctrine that judges-the agents of a

28 W. Nezson, supra note 26, at 21-28.

29 Id. 2I-23.

30 Legal Papers of Jomn Adams 230 (L. Wroth \& H. Zobel eds. 1965). 
potentially arbitrary executive-ought to follow precedent and so not alter the rules of law. For, as we have seen, the vast power of juries in general left judges with only a few rather simple law tasks, such as instructing juries and deciding pleading motions, which could be mechanically performed by looking to precedent.

Most important, perhaps, the law-finding power of juries meant that the representatives of local communities assembled as jurors generally had effective power to control the content of the province's substantive law. Because of the power of juries, the legal system could not serve as an instrument for the enforcement of coherent social policies formulated by political authorities, either legislative or executive, whether in Boston or in local communities, when those policies were unacceptable to the men who happened to be serving on a particular jury. The ultimate power of juries thus raises the question whether the judgments rendered in the courts on a day-to-day basis were a reflection more of law set out in statute books and in English judicial precedents or of the custom of local communities. $^{31}$

A distinguished historian of English law has lately noticed that legal systems which delegate law-finding functions to laymen cannot be anxious about producing a systematic substantive law, since they give professionals so few occasions to review the legal significance of facts. ${ }^{32}$ The allowance of such large latitude to laymen is jurisprudentially significant because it seems to reveal a society at home with the notion that law and right are changeless truths discoverable by lawyers and laymen alike. In such a world law is a fact like any other: all that is necessary for the resolution of a dispute is for intelligent and moral people, free from the temptations of corruption, to apply their minds to it in a reasonably diligent fashion.

This is exactly the way the common law was conceived of in eighteenth-century America, ${ }^{33}$ and this view of the law and of the capacity of jurors had an impact on procedures in those eighteenthcentury American tribunals hearing equitable matters. Practice before many of them took on a definite common-law cast. Chancery jurisdiction and practice in early America still awaits its historian,

31 W. NELSON, supra note 26 , at 28-29.

32 S. Minsom, Historucal Foundations of the Common Law 26-38 (1969).

33 See M. Horwitz, The Transformation of American Law, 1780-1860, at $4-9(1977)$. 
and until the records of the various jurisdictions become more readily accessible, general conclusions in this area are a little hazardous. Some relevant items may be advanced with confidence, however, and they indicate a bias in favor of juries even in suits in equity.

In Massachusetts, general equitable relief was unavailable in any of the courts until almost one hundred years after the adoption of the seventh amendment. ${ }^{34}$ During the colonial period acts were passed granting certain kinds of specific equitable powers to law courts: in 1693, jurisdiction to chancer bonds was given; in 1698 and 1735, power to relieve against forfeiture by mortgagors was granted; and in 1713 and 1719, jurisdiction was conferred over redemption of lands after sale under an execution..$^{35}$ In all these cases trial was by jury; and in 1791, no matters of fact material to equitable issues were tried other than by jury. ${ }^{36}$

It is well known that Thomas Jefferson favored the use of juries in chancery courts as authoritative determiners of the facts. In a proposed constitution for Virginia that he composed in 1776 , Jefferson urged that "[a]ll facts in causes, whether of Chancery, Common, Ecclesiastical, or Marine law, shall be tried by a jury . . . "37 Another Jefferson draft of 1783 contained a similar recommendation..$^{38}$ The reports of George Wythe, America's first law professor, indicate that juries were used in the Virginia High Court of Chancery to fix the value of the thing in dispute, ${ }^{39}$ or to determine the boundaries of real estate which was the subject of litigation. ${ }^{40}$ Under this procedure the chancery court would "direct an issue to be tried" by a jury in a common-law court and order a report on the result to be sent up for scrutiny. ${ }^{41}$ While the use of

34 See generally Curran, The Struggle for Equity Jurisdiction in Massachusetts, 31 B.U. L. REv. 269, 269 (1951); Woodruff, Chancery in Massachusetts, 5 L.Q. REv. 370, 383-84 (1889), reprinted in 9 B.U. L. Rev. 168, 181-82 (1929).

35 Woodruff, supra note 34, 5 L.Q. Rev. at 376 n.2, 9 B.U. L. Rev. at 174 n.26.

36 See the historical discussion by Justice Hammond in Parker v. Simpson, 180 Mass. 334, 349-50, 62 N.E. 401, 406-07 (1902).

$37 \mathrm{~T}$. Jefferson, A Bill for new modelling the form of government, \& for establishing the fundamental principles there of in future (before June 13, 1776) (third draft of Jefferson's proposed Virginia Constitution), in 1 TrE Papers of Thomas Jefrerson 362 (J. Boyd ed. 1950).

38 M. Tachau, Federal Courts in the Early Republic: Kentucky 17891816, at 180 n.32 (1978).

39 Ross v. Pleasants, Shore \& Co., Wythe 10, 22, 24 (Va. 1790) (commentary on opinion and decree of the Court of Appeals, which reversed the decree of the High Court of Chancery) (value of tobacco exchanged for land); Hinde v. Pendleton, Wythe 354, 357 ( $\mathrm{Va}$. Ch. 1791) (value of slaves auctioned fraudulently). 40 Southall v. M'Keand, Wythe 95, 97-98 (Va. Ch. 1791) (summary of proceedings), rev'd in relevant part, I Va. (1 Wash.) 337 (1794).

41 For an example of the phrase, see Wythe 98. 
juries in equity courts in England was not unknown, the frequency of resort to them, and the kinds of occasions on which resort would be had, was evidently larger in Virginia. This was clearly the case in Kentucky; a recent study of the federal court which sat there beginning in 1789 has revealed frequent use of juries in equity cases. ${ }^{42}$ The same can be said of Georgia in this period; that state "allowed trial by jury in some causes which by tradition belonged to the equity side of the bench." ${ }^{43}$ A North Carolina statute enacted in 1782 had the same aim and effect. ${ }^{44}$

William Penn, referring to the happy condition of the Indians in Pennsylvania, noted in 1683 that they "are not disquieted with bills of lading and exchange, nor perplexed with chancery suits." 45 And it is perhaps in Pennsylvania that one encounters the most extensive use of juries in chancery proceedings. There, except for a brief period in the eighteenth century, equity was administered entirely in the courts of law. ${ }^{46}$ Without chancery courts, it fell "to the lot of Pennsylvania," William Rawle said in 1868, "through necessity, to have blended together, in a single tribunal, equitable principles and equitable jurisdiction, and to have dispensed those principles through the medium of common law forms." 47 One of the short-lived acts creating courts of equity in Pennsylvania demonstrates how careful one must be in interpreting historical evidence of the times. In 1711, the common-pleas judges were empowered to sit as a court of equity four times yearly, with instructions to observe "as near as may be, the rules and practice of the high court of chancery in Great Britain." 48 Without more, this would lead to the conclusion that a jury would not ordinarily be employed. But the act went on to provide that "when matters of fact should arise in the hearing of any cause, the court should first refer them to issue and trial before the Common Pleas, before proceeding to decree in equity." 49

The lack of equitable remedies in Pennsylvania meant that the common-law courts had to improvise when persons sought enforce-

$42 \mathrm{M}$. TACHAU, supra note 38 , at 179-82.

33 L. Frnedman, supra note 18 , at 131.

44 Id. (citing ch. 11, 1782 N.C. Laws).

45 Letter from William Penn to the Free Society of Traders (Aug. 16, 1683), reprinted in $1 \mathrm{R}$. Proud, Hirstory of Pennsxuvanta 246, 255 (Philadelphia 1797). 46 Liverant \& Hitchler, A History of Equity in Pennsylvania, 37 Drck. L. Rev. $156,162,165$ (1933).

47 W. RAwLE, supra note 17, at 2 (emphasis in original).

48 An Act for Establishing Courts of Judicature in this Province, Feb. 28, 1711, ch. 168, $\$ 25,2 \mathrm{~Pa}$. Stat. (1682-1801), at 301 (repealed '1713), quoted in W. RAWLE, supra note 17 , at 16 .

49 W. RAwLE, supra note 17 , at 17. 
ment of equitable rights. Thus Horace Binney could say that this difficulty "taught us how to clothe a large body of equity principles in the drapery of the law." 50 For instance, if specific performance was sought, a substitute for an injunction had to be found, so eighteenth-century Pennsylvania courts granted "conditional damages, so large in amount, that the defendant finds it to his advantage to yield to the plantiff the equity which is the subject of the suit." 51 A case decided in 1791 nicely illustrates the use of this device.52 If specific performance of a land-sale contract was sought, then ejectment, a real action at common law offering specific recovery of the realty, was made available; ${ }^{53}$ likewise, replevin could effect the recovery of a chattel owed.". And so, "by an ingenious and liberal use of . . . common law methods," 55 the common-law courts of Pennsylvania fashioned equitable remedies for the vindication of equitable rights.

\section{B. Complexity as a Head of Equity Jurisdiction}

As noted before, early American chancery records have not yet been fully mined for the information they may contain, and general statements are therefore somewhat difficult. But it is nevertheless clear that no case of that period yet printed indicates a willingness on the part of the chancellor to assume jurisdiction because of a matter's alleged unsuitability for trial before a jury. It is true that after the seventh amendment was passed, nineteenth-century courts occasionally claimed that the basis for jurisdiction over suits for accounting in equity was the impracticality of trying them before a jury. ${ }^{56}$ But no eighteenth-century American court, so far as we

$50 \mathrm{H}$. Binney, An Eulogium upon the Hon. William Tilghman, Late Chief Justice of Pennsylvania (Oct. 13, 1827) (address to the Bar of Philadelphia), published in 16 Serg. \& Rawl. 439, 449 (Pa. 1827).

61 A. Laussat, An Essay on EquTty in Pennsxlvanta 48 (Philadelphia 1826).

52 Clyde v. Clyde, 1 Yeates 92 ( $\mathrm{Pa} .1791$ ).

53 W. RAwLE, supra note 17 , at $61-62$.

54 Id. 62.

55 A. Laussat, supra note 51 , at 57.

56 E.g., President of the Farmers' \& Mechanics' Bank v. Polk, 1 Del. Ch. 167, 175-76 (1821):

Is this such a case that the parties should be decreed to account? Upon that point I have no doubt. These transactions are so complicated, so long and intricate, that it is impossible for a jury to examine them with accuracy. They will require time, assiduous attention and minute investigation, and are involved in so much confusion and difficulty that no other tribunal, by reason of the forms of proceeding of the courts of law, can afford the plaintiff a remedy.

See Ludlow v. Simond, 2 Cai. Cas. 1, 52 (N.Y. 1805) ("The settlement of accounts, if they are in any degree long or complex, is improper, if not im- 
can tell, so held. A South Carolina case initiated in 1717,57 asking for an accounting in a partnership setting, has indeed been cited as an example of equity jurisdiction's being premised upon the complexity of the facts. ${ }^{58}$ Examination of the pleadings, however, reveals an entirely different basis for the jurisdiction: the need for the discovery and subpoena power of equity that was unavailable in the common-law courts. Plaintiff concluded her bill for equitable relief as follows:

All which Actings and doeings of the said Francis LeBrasseur [the defendant] are contrary to all Equity and good Conscience and Ministers Fresh occasion of Sorrow and Affliction to your Oratrix's late great Misfortunes well known to this Honourable Court In tender Consideration whereof and for that your Oratrix is wholly remediless in the premisses at the Common Law for that your Oratrix cannot by any Action at Law Compel the said Francis LeBrassuer [sic] to produce his said Books of Accounts and Consequently cannot Ascertain her Damages to a Jury occasioned by the said LeBrassuer [sic] his breach of the Covenant of the aforesaid Indenture of Copartnership nor can your Oratrix Sufficiently prove at Common Law the said Collaterall Verbal Agreement or the Stock advanced by your Oratrix pursuant thereunto or the proffits accrewing to your Oratrix therefrom without Sight Perusal and Examination of said Books of Accounts . . . . Wherefore . . . May it please your Honours to Grant unto your Oratrix the Writt of Subpena to be Directed to the said Francis LeBrasseur . . . and Alsoe to Grant unto your Oratrix the Writt of Duces tecum to be directed to the said Francis LeBrasseur requiring him at a Certain Day to bring in and Deposit in this Honourable Court all the said Old partnership Books of Accounts . . . And all papers Minuments and Writings relating to the said Copartnership.... . 69

practicable for a jury."). For discussion of difficulties in accounting cases, see text accompanying notes $92-96$ infra.

57 Bill of Complaint, Wright v. LeBrasseur (filed Sept. 23, 1717), reprinted in Reconds of the Court of Chancery of South Carolina, 1671-1779, at 208 (A. Gregorie ed. 1950).

58 The editor of the case states that the basis for seeking equitable jurisdiction here was that a jury was "entirely unfitted to deal with the complexities of facts usually involved in such an accounting," but there is nothing whatever in the case to support this assertion. Reconds of THE Court of CHancery of South Carolna, 1671-1779, at 47 (A. Gregorie ed. 1950).

59 Bill of Complaint, supra note 57, at 216-17 (emphasis added). 
Nowhere does the bill mention the complicated character of the case. Indeed, even if one were to discover in the eighteenth-century archives a case in which equitable jurisdiction rested on complexity, it would prove only that complexity was a basis for providing an equitable remedy at the option of the plaintiff. It would not even suggest the possibility that a plaintiff seeking a legal remedy proper to the circumstances could be enjoined from doing so.

\section{Equity and Complex Cases in Eighteenth-Century England}

In a recent Article on suits at common law in eighteenthcentury England, Lord Devlin has argued that the chancellor would sometimes intervene in complex cases "to prevent a purely legal claim from being tried by jury", ${ }^{80}$ and that "[t] he English judicial attitude toward putting such a task upon a jury has been unchanged over two centuries . . . ." 61 The abandonment of the jury in England in recent times is a fact too notorious to dispute, ${ }^{62}$ but, with respect, the assertion that significant antecedents of this attitude existed in a much earlier period is not easily maintained. Indeed, only two cases are cited in favor of this proposition, and examination reveals them to be much too frail to support the large reliance placed upon them.

Towneley $v$. Clench, ${ }^{63}$ a chancery suit decided by Ellesmere in 1603 , is the first such case, and, although quite interesting, it is terribly obscure. The short report as Cary has it follows:

Inter Tomley and Clench, it appeared by testimony of ancient witnesses speaking of sixty years before, and account books and other writings, that Francis Vaughan, from whom Tomley claimed, was mulier [i.e. legitimate]; and Anthony, from whom Glench claimeth, was a bastard; and the possession had gone with Tomley fifty years. In this case the Lord Egerton not only decreed the possession with Tomley, but ordered also that Clench should not have any trial at the common law for his right till he had shewed better matter in the Chancery, being a thing so long past; it rested not properly in notice de pais, but to be discerned by books and deeds, of which the Court was better able to judge then a jury of ploughmen, notwith-

60 Devlin, supra note 1 , at 74 .

61 Id. 76.

62 See, e.g., J. Baker, An Introduction to English Legat Histort 80.81 (2d ed. 1979).

63 Clench v. Tomley, Cary 23, 21 Eng. Rep. 13 (Ch. 1603). The report in Cary reverses the parties and misspells the plaintiff's name. 
standing that exceptions were alleged against those ancient writings; and that for the copyhold land, the verdict went with Glench upon evidence given three days before Serjeant Williams that Anthony was mulier (31st May, 1 Jacob. 1603). ${ }^{64}$

In order to understand why it is so difficult to interpret this report with real confidence it is first necessary to recall the nature of early seventeenth-century reporting. Reports in this period were in no sense "official"; indeed, official reports would not appear in England or America until well after the seventh amendment was adopted. ${ }^{65}$ Until then, the books printed as "reports" could have had several different original purposes: they might have been, as in the medieval Year-Book tradition, the notes of students present in court; ${ }^{66}$ or they might have been the notes of counsel or judges participating in the litigation. ${ }^{67}$ In no sense were they complete: not every case was reported, and not every aspect of reported cases received attention. Rarely was there anything resembling the opinions of modern American law reports. Most likely this was because the breadth of the jury's power over results left professionals few opportunities to speak on the legal significance of facts. Not until the early nineteenth century did anxiety over the power and authority of judges produce demands for official reports. Before then, the idea of stare decisis was simply not well established in substantive matters and the need for control of judge and jury was not a cause for great concern. ${ }^{88}$

Against this background the relatively unscientific and imprecise character of early reports is easy to understand. The reporter in Towneley $v$. Clench does not even bother to tell us the exact nature of the bill initiating the suit. A first reading of the case suggests that it might well belong to a class of land cases that equity began to entertain in the sixteenth century because one party was withholding "deeds and evidences" from the other; 69 those cases seem to be prototypes of that head of equity jurisdiction grounded

$64 I d$. (emphasis in original). (1884).

65 See generally W. Danier, The Hustory and Orugin of tae Law Reports

66 See J. BAKER, supra note 62, at 152-53; Introduction to 1 YEAR Books of Edward II, at ix, xiii (F. Maitland ed.) (Selden Society Vol. 17, 1903).

67 See J. Baker, stpra note 62, at 153-58; J. Dawson, The Oracles of the LAw 76 (1968). Many of the cases reported by Coke were of this variety.

68 This is one theme of J. Dawson, supra note 67, Ch. I passim.

69 Dr. Edith Henderson of the Harvard Law School very kindly suggested this possibility to me. 
on the availability of discovery in chancery. One could also speculate-and there is nothing in the meagre report to indicate otherwise-that the case was brought evoking the quia timet jurisdiction of equity. In light of these alternative possibilities, it seems highly unwarranted, simply on the evidence of the report in Cary, to take the unprecedented view that the basis for equity jurisdiction was the complexity of the case.

A search of the early chancery records in the Public Record Office in London ${ }^{70}$ has now revealed the actual basis for invoking equitable jurisdiction in Towneley $v$. Clench. The bill recites that Bedolph, a co-defendant, had taken the plaintiff's "evidences of title" from the plaintiff's servant by force. These evidences came into the possession of the defendant Clench, making it impossible for the plaintiff's lessee to defend against an ejectment suit which Clench's lessee brought at law. ${ }^{71}$ The bill also mentions the difficulty that most of the pertinent witnesses were in the islands of Guernsey and Jersey. It explains further that the defendant claimed by virtue of the right of his wife Mary Clench, ${ }^{72}$ who claimed through Anthony Vaughan, the bastard son of Sir Hugh Vaughan, and that the plaintiff claimed as the devisee of Sir Hugh's legitimate son Francis. The plaintiff therefore prayed a subpoena. ${ }^{73}$ Within two weeks the defendant answered, setting out the claim of title which the plaintiff had attributed to him but denying that Anthony was a bastard.74 Three months later Francis Bacon, on behalf of the plaintiff informed that his client had been in peaceable possession for forty years and that the defendant was claiming through Anthony, who was "known to have been a bastard." 75 The court issued a temporary injunction against the ejectment proceedings at law "until the matter should be determined in Chancery." "76 The next month the defendant successfully requested

${ }^{70} \mathrm{Dr}$. J. H. Baker of Cambridge very kindly made the search of the records for me and furnished me with abstracts and transcripts on which the following discussion is based. All quotations, unless otherwise noted, are from Dr. Baker's notes, which are paraphrases of the original records in modern English spelling. A copy of Dr. Baker's notes is on file with the University of Pennsylvania Law Review.

71 Bill on behalf of Francis Towneley, Towneley v. Clench (sworn Jan. 24, 1600 [i.e., 1601]), Public Record Office, London, [hereinafter cited as P.R.O.] C2/Eliz/T3/60.

72 The defendant was Thomas Clench of Lincoln's Inn.

73 P.R.O. C2/Eliz/T3/60 (Jan. 24, 1600 [i.e., 1601]).

74 Answer of Thomas Clench, Towneley v. Clench (sworn Feb. 7, 1600 [i.e., 1601]), P.R.O. C2/Eliz/T3/60.

is P.R.O. C33/99, fol. 462v (May 7, 1601); id. C33/100, fol. 450.

76 Id. 
an order requiring the plaintiff to find a surety for the mesne profits. ${ }^{77}$

There followed some procedural skirmishing which lasted more than a year. Then, in May of 1602, the defendant Clench moved that the injunction be lifted "since the principal question is whether Anthony Vaughan was a bastard, which is meet to be tried at common law." 78 In June, the court denied the motion, partly on the ground that the "plaintiff does not wholly insist on the point of bastardy but upon some other question." 79 Final judgment was not rendered until almost a year later, on May 31,1603 . The decree stated as a finding of fact that Anthony was a bastard, born to Dame Blanch, the last wife of Sir Hugh, before they were married and during his prior marriage to Dame Anne Hungerford, whereas Francis, through whom the plaintiff claimed, was a legitimate son of Sir Hugh and Dame Blanch. ${ }^{80}$ The court indicated that this finding was supported by much evidence. First, the court rolls from several manors of presentments made in the time of Queen Mary stated that Francis had been found heir to George the eldest (legitimate) son of Hugh despite the fact that depositions of witnesses read in court indicated that Anthony was much older than George. Second, Sir Hugh's will entailed the lands first to George, then to Francis, and then to Anthony; this was taken as circumstantial evidence that Anthony was not legitimate. The court's conclusions are worthy of full quotation:

[T]herefore, and because it appeareth that the possession of the said lands hath for the space of about fifty years gone and continued with the said Francis Vaughan and with the plaintiff who claims from him, and that the plaintiff's evidences concerning the said lands were by force and violence taken away by the said Bedolph [a codefendant] from the plaintiff's servant as he was carrying them in the open street, and the same were shortly after brought to the said Clench by the said Bedolph, whereby it is supposed the plaintiff may be disabled to maintain his title at the common law, It Is Ordered Adjudged and Decreed by This Court that the plaintiff . . . hold . . . the possession of the manors, lands and tenements . . . until better matter shall be showed in this Court to the contrary. ${ }^{81}$

77 P.R.O. C33/99, fol. 672 (June 26, 1601).

78 P.R.O. C33/102, fol. 584 (May 17, 1602).

79 P.R.O. C33/102, fol. $674 \mathrm{v}$ (June 14, 1602).

80 P.R.O. C33/103, fol. 681 (May 31, 1603). supra).

81 Id. (direct quotation with spelling modernized by Dr. Baker, see note 70 
A number of interesting and pertinent observations are made possible by this new evidence on the nature of the dispute in Towneley v. Clench. For one thing, it is significant that the plaintiff at no time made the claim that equitable jurisdiction rested on the complexity of the case. Indeed, the facts seem remarkably simple. The difficulty, as the record reveals, was that legal process in the law courts was inadequate for Towneley in two ways: first, there was no subpoena power to compel the production of the purloined documents; second, there was no power to compel witnesses to appear. The first difficulty could be overcome in equity by ordering a return of the documents, although Towneley seems never to have accomplished this; the second evidently was overcome by taking the depositions of the pertinent witnesses. Thus the obvious basis for jurisdiction was the superior process available in equity.

Moreover, the decree itself does not mention the supposed inferiority of jury trial as a reason for denying the defendant his right to sue at common law. It mentions only the plaintiff's apparent right and the fact that the defendant had contrived to render the plaintiff's defense at law impossible. When the decree says that the injunction will be lifted only if "better matter shall be showed," the meaning is clear: the defendant has possession of the relevant documents and he can come forward with them if he believes them helpful to his cause. The decree proceeds on the assumption that the relevant evidence was being withheld, not that it would be too complex for the jury if it were made available. Thus, the records of the proceedings indicate that the official reasons for denying the defendant his ordinary recourse to law were unremarkable, routine, and wholly unrelated to the mode of trial afforded by the commonlaw courts.

Even if we assume, arguendo, that Ellesmere made the condescending statement attributed to him by Cary, ${ }^{82}$ it does not follow that the Chancellor meant to create a new font of equity jurisdiction grounded in complexity. One needs to recall that in this period the jury was still said to possess an investigative function and might be expected to come to court with some knowledge of the facts. This suggests that Ellesmere can be understood to have found simply that cases requiring notice of ancient facts are not suitable for jury trial. ${ }^{83}$ According to this interpretation, Ellesmere's ob-

82 See text accompanying note 64 supra. Dr. Baker was unable to locate any report of the case other than that made by Cary.

83 Hence Cary's report says, speaking of the critical event in the case: "being a thing so long past; it rested not properly in notice de pais." Towneley v. Clench, 
jection that a "jury of ploughmen" might not be the most competent body to examine and understand account books and writings is thus beside the point. In any case, the law courts would soon attempt to overcome such objections by making the interpretation of most documents a matter of law.

In the days before they became official, law reports often featured asides from those who were doing the reporting. This was an old tradition, and sometimes some fairly unflattering remarks about judgments were preserved. At the end of the report of Towneley $v$. Clench, the reporter, said to be Mr. William Lambert, ${ }^{84}$ indicates his surprise over, and disagreement with, Ellesmere's conclusion. He implies that the decision cannot be supported because the evidence relied upon was controverted by Clench, and he points out, moreover, that Clench had only recently won a judgment for copyhold land on the same evidence. The record of the case supports the reporter on this point by revealing that the court actually quieted the title to this land in Clench on his motion. ${ }^{85}$ In any event, Ellesmere's novel opinion was apparently never regarded as authority later, and there is no evidence that its principles, whatever they might have been, were ever again invoked. Indeed, Towneley $v$. Clench is so obscure that it had entirely escaped the notice of most commentators until recently, when it became necessary to ransack the old books in search of a distinguished parentage for what is really a relatively new idea-that a jury may be denied a plaintiff on the ground that the case is "too complex." The most recent scholarly look at the clash between law and equity in the seventeenth century does not even so much as mention the case. ${ }^{86}$

Finally, in assessing the significance of Ellesmere's remark, one needs to keep in mind that the Lord Keeper's imperious style was not regarded as something worthy of emulation by his successors. His hostile and competitive feelings toward the law courts of the age, and in particular his difficulties with Coke, have not left his memory entirely unblemished. In the years following his time as Chancellor, law and equity learned to accommodate each other, and the condescending attitude toward juries attributed to Ellesmere by Cary would not have won the approval of succeeding generations.

Cary 23, 21 Eng. Rep. 13 ( $\mathrm{Ch}$. 1603). This rationale, of course, can have no application to modern juries.

$84 \mathrm{~J}$. Watrace, The Reporters 469 (4th ed. 1882) (Ist ed. Philadelphia 1844). 85 P.R.O. C33/99, fol. 672 (June 26, 1601).

86 See generally L. Knafla, Law and Politics in Jacobean England (1977). 
The second English case said to support the view that equity would claim exclusive jurisdiction over complex cases is Blad $v$. Bamfield, ${ }^{87}$ decided by Lord Nottingham in 1674. Bamfield and other Englishmen brought common-law actions against Blad, a Dane, for seizing goods from their ships plying the waters of Iceland. Blad brought suit in chancery to stay the proceedings at law, alleging that the King of Denmark had by patent granted him a monopoly which the defendants had violated. Bamfield replied that such a patent, if proved, would be illegal and a breach of a recent treaty. In granting Blad's prayer for a permanent injunction, the Lord Chancellor noted that the case properly belonged to chancery because it was a trespass on the high seas and chancery had admiralty jurisdiction; an action at common law would mean that the court would have to "pretend to judge of the validity of the king's letters patent in Denmark, or of the exposition and meaning of the articles of peace." 88 Moreover, he counted it "monstrous and absurd" to allow a "common jury" to "try whether the English have a right to trade in Iceland." 89 This case stands for the simple proposition that suits involving foreign relations ought to be tried in prerogative courts: it is not the complexity of the case which renders it unsuitable for trial in a common-law forum, but the source of the rights claimed. Today, of course, there would be no reason why such cases could not be submitted to juries: ample jurycontrol techniques exist so that complicated matters of foreign and domestic law may ultimately be ruled on by judges.90 Certainly there is no longer any concept like that of a prerogative court which stands in the way. On any reading, the case gives slim support to the view that complexity is a reason for withdrawing a case from a jury.

\section{CONCLUSION}

It is true that the claim was made in the nineteenth century that certain cases, including those involving accounts, belonged to the concurrent jurisdiction of law and equity because they were in some sense "complex." So Mr. Justice Story, a champion of equity who, as a young Massachusetts legislator, introduced an abortive bill to create a chancery court there, ${ }^{91}$ complained early in that

873 Swan. 604 (App.), 36 Eng. Rep. 992 (Ch. 1674).

88 Id. 607, 36 Eng. Rep. at 993 (emphasis in original).

$80 I d$. (emphasis in original).

90 See Note, Preserving the Right to Jury Trial in Complex Civil Cases, 32 StaN. L. REv. 99, 116-20 (1979).

91 Curran, supra note 34 , at 274 . 
century of the difficulty of trying commercial cases to juries. ${ }^{92}$ It may well be that Story's objection to jury trials in such cases was that the jury might have difficulty in understanding the matters in issue; we have seen that in this period such claims were being made.93 But the original extension of equity into the accounting area could not have been on this ground because juries did not try accounts anyway; they merely determined whether the defendant ought to be put to an accounting before auditors. Indeed, Blackstone attributes the entry of equity into the area of accounting to the availability of discovery in equity courts. ${ }^{94}$ In any case, accounting is an obvious area for equity to occupy: it usually involves relationships which entail fiduciary obligations, and even the old legal action of account recognized that fact in determining amounts due from accountants..$^{95}$

In 1791, the year of the adoption of the seventh amendment, James Wilson delivered his famous law lectures at the University of Pennsylvania. Noting the virtual demise of the action of account at law, he laid that decline to the action's complexity. But it was not the jury's inability to understand that gave him concern. He explained:

Accounts never were, by the course of the common law, brought to trial before a jury. To a jury, indeed, the general question-ought the party to account-was submitted for its determination. But the adjustment of the accounts was submitted to auditors, instead of being tried by a jury. If, upon any article in account, the auditors cannot agree; or, if agreeing, the parties are not satisfied; then, upon each point, so litigated, a separate and distinct issue may be taken, and that issue must be tried by a jury. In this manner, a hundred issues may be joined in the same cause, and tried separately by as many juries; but the general statement of the disputed accounts still remains before the auditors, and by them the general result from the whole must be formed and ascertained. This mode of liquidating accounts judicially at common law, is obviously exposed to many disadvantages and delays; and, for this 1835).

92 1 J. Story, Commentaries on EQuTty JuRtsprudence $\$ 451$ (Cambridge

93 See notes 2 \& 3 supra \& accompanying text.

943 W. Blackstone, Commentarues 437.

95 Chief Justice Belknap, for example, expressed the view that a receiver who did nothing to make his receipts productive "will be charged for reasonable profits." Hastynges v. Beverley, Y.B. Pasch. 2 Rich. 2 (1379), reprinted in Year Boors of Ruchard II 121, 122 (M. Arnold ed. 1975). 
reason, the action of account has, in a great measure, fallen into disuse. In England, the parties in unsettled and litigated accounts have recourse to chancery; in Pennsylvania, to arbitrators, or to jurors acting in the character of arbitrators. ${ }^{96}$

Wilson offered these remarks to demonstrate why the action was only rarely chosen by plaintiffs; nowhere does he suggest that trial by jury was not available at the plaintiffs' option.

A diligent search of the available sources has not revealed any evidence of an eighteenth-century American or English belief that complexity was a ground for the exercise of equitable jurisdiction. In the nineteenth century, statements to that effect can be discovered but their lineage is in no sense ancient or otherwise distinguished. On the contrary, there is ample evidence that the jury was revered in most of the American colonies, so much so that jury trial found a regular place in chancery, a practice that would have raised eyebrows in England. Finally, even if one were to concede the existence of an eighteenth-century head of equitable jurisdiction premised on complexity, it would nevertheless be true that the cases said to support it give no indication at all of a jurisdiction that is exclusive. There thus seems to be no good historical foundation for the argument that plaintiffs may be denied the right to a jury trial because their cases are complex. As we have noted, ${ }^{97}$ such arguments are hardly new; but it is only recently that they have come to be countenanced in the courts. ${ }^{98}$

962 The Works of JAMEs Wilson 492 (R. McCloskey ed. 1967).

97 See text accompanying notes 2-3 supra.

98 See ILC Peripherals v. IBM Corp., 458 F. Supp. 423 (N.D. Cal. 1978); Bernstein v. Universal Pictures, Inc., 79 F.R.D. 59 (S.D.N.Y. 1978); SEC v. Associated Minerals, Inc., 75 F.R.D. 724 (E.D. Mich. 1977); In re U.S. Financial Sec. Litig., 75 F.R.D. 702 (S.D. Cal. 1977), rev'd, 609 F.2d 411 (9th Cir. 1979); Jones v. Orenstein, 73 F.R.D. 604 (S.D.N.Y. 1977); In re Boise Cascade Sec. Litig., 420 F. Supp. 99 (W.D. Wash. 1976). 